the codes is not undesirable in circumstances where it does not substitute a trial on affidavits for a normal trial. This is true where the plaintiff has not used reasonable diligence in prosecution, since the question to be decided is not based on the facts of the case but rather on whether the plaintiff should be permitted any trial at all due to his laches.

In other situations the use of this procedure seems undesirable. While none of. the reported cases reveal any substantial harm to a plaintiff, allowing the issue of res judicata to be raised by this method does present the possibility of such harm. Best v. Fitzgerald, ${ }^{28}$ the most recent case allowing the motion, illustrates this. Although the facts given in the report do not indicate that plaintiff was deprived of a normal trial, the broad rules of law set forth by the court in its short opinion, ${ }^{20}$ without the qualifications formerly expressed, ${ }^{30}$ give rise to the possibility that these qualifications may be overlooked by future courts and substantive harn result to the plaintiff. And, where the issue of whether a case is fictitious or sham is allowed to be raised by a motion to disniss, as it was in Cunha v. Anglo California $\mathrm{Na}$ tional Bank, ${ }^{31}$ where the only real dispute is over the facts of the case there would seem to be considerable likelihood of deprivation of a normal trial. ${ }^{32}$ The summary judgment procedure has been specially designed for use in such a case as this and would seem preferable. ${ }^{33}$

\title{
REAL PROPERTY: EASEMENTS: CREATION BY RESERVATION OR EXCEPTION
}

When $A$ conveys a parcel of land to $B$ and by the same instrument attempts to retain a right of way across the parcel, there arise several problems concerning the legal nature and effectiveness of his creative act.

23 Supra note 16.

$20 \mathrm{Id}$. at $1131,185 \mathrm{P} .(2 \mathrm{~d})$ at 388 . The court gives the rules as " . . our Supreme Court has beld that the defense of res judicata may be raised on a motion to dismiss. Such a motion may be supported by affidavits setting forth the facts which tend to prove the grounds of the motion."

30 Olwell v. Hopkins, sicpra note 14.

31 Supra note 13.

32 As plaintiff failed to submit any counter-affidavits, and thus no triable issue of fact was raised, it is possible that the Cunha case could have been supported on the ground that the procedure followed was in essence that provided for under the summary judgment section. It would not be objectionable if the courts were to look at substance rather than form and see that the parties are safeguarded; however, the court did not consider this point but placed its affirmance on an inherent power of courts to decide this issue on a motion to dismiss.

${ }^{33}$ Section $437 \mathrm{c}$ does not permit the use of a summary judgment procedure in all types of cases but, in general, it is limited to actions on a contract or affecting real property. However, it would seem that this limitation is a reason for contending that section $437 \mathrm{c}$ should be extended to cover more cases, rather than a reason for permitting the substitution of a motion to dismiss. 
Early recognition was afforded to reservations of rent to the grantor. ${ }^{1}$ Technically the term "reservation" refers only to interests "issuing from" land in a legal sense, such as rents. ${ }^{2}$ The meaning of the term often has been extended, however, to include easements and profits. ${ }^{3}$ Thus $A$ 's purpose may be accoinplised by reservation. ${ }^{4}$ English courts, speakimg often in different terms, have achieved essentially the same results by construing words of reservation as words of grant."

Other courts have recognized this type of creative act as an "exception." Traditionally, "exception" referred to a qualification of the description of the granted property so as to withhold from the grant part of the thing which otherwise would have passed to the grantee. ${ }^{7}$ Convincing theoretical argument has been made, however, that this situation really involves excepting, not a portion of the soil, but rather certain rights in the parcel, and that thus there is no substantial objection to applying the term to some group of rights less than all possible rights in that parcel. ${ }^{8}$ This view emphasizes the $s e p-$ arative aspects of the transaction-dividing up rights which were formerly held by a single party-and makes no distinction between a

1 Whitlock's Case (1609) 8 Co. 69b, 77 Eng. Rep. 580; Harrington v. Wise (1596) Cro. Eliz. 486, 78 Eng. Rep. 737; Co. LITT. *47a, $* 143$ a.

2 Durham \& S. Ry. v. Walker (1842) 2 Q. B. 940, 967, 114 Eng. Rep. 364, 374; Doe d. Douglas v. Lock (1835) 2 A. \& E. 705, 743, 111 Eng. Rep. 271, 287; Co. IITT. *47a.

3 Claflin v. Boston \& A. Ry. (1892) 157 Mass. 489, 32 N. E. 659; Wickham v. Hawker (1840) 7 M. \& W. 63, 151 Eng. Rep. 679; Moore v. Earl of Plymouth (1819) 3 B. \& Ald. 66, 106 Eng. Rep. 587; Chetham v. Williamson (1804) 4 East 469, 102 Eng. Rep. 910. Even Lord Coke seems at times to recognize this usage. Co. LITT. *143a.

4 Claflin v. Boston \& A. Ry., supra note 3; Riefler \& Sons v. Wayne S. W. P. Co. (1911) $232 \mathrm{~Pa} .282,81$ Atl. 300.

5 " . . . a right of way cannot, in strictness, be made the subject either of exception or reservation. It is neither parcel of the thing granted, nor is it issuing out of the thing granted, the former being essential to an exception, and the latter to a reservation. A right of way reserved ... is . . . an easement newly created by way of grant from the grantee .... [Execution by the grantee] would be essential in order to establish the easement claimed ...." Durham \& S. Ry. v. Walker, supra note 2. Accord: Wickham v. Hawker, supra note 3.

The now virtually exclusive use of the deed poll renders this dispensation of small practical value. It is seldom that the grantee executes the deed with formahties sufficient to comprise a regrant. Since 1925, however, in England a reservation comprises a regrant by operation of law, even though not executed by the grantee, whether the reservation is in favor of the grantor or of a third party. The Law of Property Act, 1925, 15 GEo. V, c. $20, \S 65$. note 3.

${ }^{6}$ Ring v. Walker (1895) 87 Me. 550, 33 Atl. 174; Claflin v. Boston \& A. Ry., supra

7 Authorities cited note 2 supra.

8 Bigelow and Madden, Exception and Reservation of Easements (1924) 38 HARv. L. REv. 180, 187-191. However, the contrary contention has been made that an easement is not a proper subject of an exception, but rather of a reservation. 4 TIFINAY, RaAr Property (3d ed. 1939) § 973. 
separation of the area into parcels and a separation of the various rights, already existing, which comprise ownership.

There may be certain rights in land-those which were the historical subjects of "reservation"-which are not truly susceptible of "exception," having no prior existence as a part of the rights of the owner of the fee. Thus, while the owner has a right to cross his land, to gather crops, or to extract minerals, it may be inaccurate to say that he has a right to rents from the land. This semantic difficulty should not confound modern courts, however, and they should be able to interpret "reservation" and "exception" interchangeably to effect the purpose of the grantor. ${ }^{9}$

Though reservations and exceptions in favor of the grantor are thus generally given effect, great difficulty arises where the exception or reservation is in favor of a third party. It is generally said that neither a reservation ${ }^{10}$ nor an exception ${ }^{11}$ can create any title in a

9 "The words of a contract are to be understood in their ordinary and popular sense, rather than according to their strict legal meaning; unless used by the parties in a technical sense . . . " CAI. Crv. CoDE \$ 1644. This provision was applied to a grant, construing "reservation" to mean "exception" where that meaning apparently was intended. Van Slyke v. Arrowhead etc. Power Co. (1909) 155 Cal. 675, 102 Pac. 816. Cf. Sutter Buttc C. Co. v. Richvale Land Co. (1919) 40 Cal. App. 451, 181 Pac. 98 ; Ring v. Walker, supra note 6; Martin v. Cook (1894) 102 Mich. 267, 60 N. W. 679; Riefler \& Sons v. Wayne S. W. P. Co., supra note 4.

Probably the courts generally do not mean that "reservation" and "exception" are not to be distinguished, but rather that if the interest in question is properly a subject of the one, its nature is not changed by labeling it as the other. Sears v. Ackerman (1903) 138 Cal. 583, 72 Pac. 171; Butler v. Gosling (1900) 130 Cal. 422, 62 Pac. 596. In practice, however, there appears no reason to inaintain the distinction at all.

10 Elliott v. McCombs (1941) 17 Cal. (2d) 23, 109 P. (2d) 329; Boyer v. Murphy (1927) 202 Cal. 23, 259 Pac. 38, (1927) 1 So. CasIF. L. Rev. 81; Butler v. Gosling, supra note 9; Mott v. Nardo (1946) 73 Cal. App. (2d) 159, 166 P. (2d) 37 ; Haverhill Savings Bank v. Griffin (1903) 184 Mass. 419, 68 N. E. 839; Lemon v. Lemon (1918) 273 Mo. 484, 201 S. W. 103; Tuscarora Club v. Brown (1915) 215 N. Y. 543, 109 N. E. 597 ; Beardslee v. New Berlin L. \& P. Co. (1912) 207 N. Y. 34, 100 N. E. 434; Doe d. Douglas v. Lock (1835) 2 A. \& E. 705, 111 Eng. Rep. 271; Moore v. Earl of Plymouth, Chetham v. Williamson, both supra note 3. But of. Gibbons v. Ebding (1904) 70 Ohio St. 298, 71 N.E. 720 , where the words "to be used in common" were construed as a reservation creating a right of way, even though the reservation was in part in favor of strangers to the grant and to the title; Osborne v. Auburn Telephone Co. (1907) 189 N. Y. 393, 82 N. E. 428, where a reservation of a way in favor of the public was afforded recognition.

The English courts have given effect to a reservation in favor of a third party by construing words of reservation as words of regrant. Wickham v. Hawker, sitpra note 3.

The rule agamst reservations in favor of third parties is found initially in connection with rents. Co. LITT. *47a, *143b, *213b; Whitlock's Case, supro note 1. It may well have had its origin in the tenure relationship whicb supported the reservation of rents. Unfortunately, when courts accorded "reservation" an expanded meaning, they carried over this restriction to the new field. Restatement, Property, Explanatory Notes $\$ 24$ (Tent. Draft No. 8, 1937).

11 Butler v. Gosling, supra note 9; Deaver v. Aaron (1925) 159 Ga. 597, 126 S. E. 382 ; Tuscarora Club v. Brown, Beardslee v. New Berlin L. \& P. Co., Doe d. Douglas v. Lock, all supra note 10; Moore v. Earl of Plymouth, Chetham v. Williamson, both supra note 3. But $c f$. Gibson v. Porter (1891) 12 Ky. L. Rep. 917, 15 S. W. 871, where an exception of a way in favor of a stranger was given effect, the court speaking in terms of a covenant running with the land. 
stranger. While an attempted reservation to a stranger is frequently said to be wholly ineffective, ${ }^{12}$ an exception in favor of a stranger prevents the excepted interest from passing to the grantee, leaving it in the grantor. ${ }^{13}$ Some courts have given similar limited effect to reservations by construing them as exceptions. ${ }^{14}$ In applying the rule preventing a third party from taking an interest, some cases have made a distinction between a "stranger to the title" and a "stranger to the grant." Thus it is said that where the party participates as a grantor, but has no prior interest in the property conveyed, he can take no interest by reservation..$^{15}$ Undesirable as this distinction may be as a further techmical doctrine which may thwart the grantor's purpose, it appears to be not without historical justification, at least with respect to reservations. The reservation is found earliest in connection with rents, the right to which was based initially on a relation of tenure. Thus when it was said that a rent could not be reserved to a stranger, it seems probable that "stranger to the title" was meant. The joining of a volunteer as a party grantor could hardly have been a sufficient substitute for the tenure relationship.

Some courts, while denying that a stranger to the deed may take an interest thereby, say that the grantee may be estopped to raise the question, having taken his estate under the same instrument. ${ }^{16}$ Others,

12 Boyer v. Murphy, Lemon v. Lemon, both supra note 10.

13 Deaver v. Aaron, supra note 11; Lemon v. Lemon, supra note 10; Bartlett v. Barrows (1901) 22 R.I. 642,49 Atl. 31.

14 Cases cited note 13 supra.

It should be noted tbat an exception or reservation may operate to recognize and thereby preserve under the recording acts rights of the third party which were in existence at the time of the conveyance. Deavor v. Aaron, supra note 11 ; Bartlett v. Barrows, supra note 13. But the effect of this is merely to charge against the grantee rights already existing and not to create any new interest in the stranger. 4 TnFFANY, op. cit. supra note $8, \S 975$.

15 Though he is a party to the deed, he is still a "stranger to the title," and remaims within the prohibition of the rule. Lemon v. Lemon, supra note 10. This view is strengthened by the fact that certain English cases which have dealt with the problem have involved "strangers to the title" who were joined as grantors. Wickham v. Hawker, Moore v. Earl of Plymouth, Chetham v. Williamson, all supra note 3.

Although discussed, the point is expressly reserved in Boyer v. Murphy, supra note 10. But it has since appeared that Cahfornia recognized the distinction with respect to both exceptions and reservations, applying the rule of Lemon v. Lemon. Mott v. Nardo, supra note 10.

16 Beinlein, etc. v. Johns, etc. (1898) $102 \mathrm{Ky} .570,44 \mathrm{~S}$. W. 128; Litchfield v. Boogher (1911) $238 \mathrm{Mo} .472,142 \mathrm{~S}$.W. 302 . And the reservation may preclude interference by the grantee, even though it does not effect a conveyance to the stranger. Hodge v. Boothby (1861) $48 \mathrm{Me} .68$.

Where a vendee contracted to take a deed containing a reservation in favor of a third party, he was later estopped to deny that party's interest. Sutter Butte C. Co. v. Richvale Land Co., supra note 9.

Compare "A reservation or an exception in a conveyance will not confer title upon a stranger to the instrument, although under certain circumstances it may operate as an admission in his favor, or as an estoppel against the grantor," [Italics added] Butler v. Gosling, supra note 9 at 426, $62 \mathrm{Pac}$. at 297, with "Since the reservation in the deed 
adhering to the traditional view, point out that this estoppel exception devours the rule. ${ }^{17}$

An additional problem involved in giving effect to an exception or reservation in favor of a third party arises in overcoming the technical objection of the absence of operative words of grant. ${ }^{18}$ In view of the generally liberal approach of the California courts to such matters, this difficulty does not appear insurmountable. ${ }^{10}$

Against such a complex background Civil Code section $1085^{20}$ became law in 1872. The provision seems to have been overlooked consistently by the appellate courts. ${ }^{21}$ There is also a total absence of

to Stamps [grantee] did not vest in Avery [stranger] any interest in the easement, the bank [grantor] and its successors were free to dispute any claim asserted by Avery or his assigns," Mott v. Nardo, supra note 10 at 164, 166 P. (2d) at 40.

17 Beardslee v. New Berlin L. \& P. Co., supra note 10.

18 E.g., McGarrigle v. R. C. Orphan Asylum (1905) 145 Cal. 694, 695, 79 Pac. 447, where the following language was held to create no effective remainder: "It is the purpose of the party of the first part by this deed, that ... the said described lands shall become and be the property of the Roman Catholic Girls' Orphan Asylum ...." [Italics added.]

10 Where the grant to a son "and to his heirs forever" contained the following, "The intention of the grantor herem is a life estate to his son the said party of the second part, and at his death to become the property of the said party of the second part's children," the court held that, despite the language of the granting clause giving the fee to the son, the intent was clear, and the children took an interest by virtue of the deed. Leala v. Caroll (1929) 207 Cal. 542, 543, 279 Pac. 443.

In Brusseau v. Hill (1927) $201 \mathrm{Cal} .225,227,256 \mathrm{Pac} .419,420$, the court found the following sufficient words of grant: "This is my gift of deed all is in my possession to Mr. G. W. Brusseau after my deat."

A federal district court, applying California law, considered several letters, expressing the purpose of the "grantor" that the property presently belonged to the "grantee," to comprise a sufficient grant. Metzger v. Miller (N.D. Calif. 1923) 291 Fed. 780, (1924) 22 MICH. L. REv. 373.

Language in a deed that the estate shall "revert" to a stranger upon the termination of a life estate in the grantee has been interpreted as a sufficient grant of a remainder to a stranger. Hughes v. Scott (1920) 47 Cal. App. 264, 190 Pac. 643. "Reserve" and "except" seem to have no more technical meanings than "revert," and thus there is no reason for giving them different treatment.

But cf. McGarrigle v. R. C. Orphan Asylum, supra note 18; Litten v. Warren (1936) 11 Cal. App. (2d) 635, 54 P. (2d) 39, (1936) 24 CaLtr. L. Rev. 468.

20 "A present interest, and the benefit of a condition or covenant respecting property, may be taken by any natural person under a grant, although not named a party thereto." CaI. CIV. Code § 1085.

21 Despite the presence of section 1085 on the books since 1872, California cases have continued to lay down the rule prohibiting a stranger's taking an interest by exception or reservation. Elliott v. McCombs, Butler v. Gosling, Mott v. Nardo, all supra note 10 . But where certain land was the separate property of the wife, and the husband and wife joined in a deed conveying the land and "reserving" a life estate to the grantors, the reservation was construed as an exception, and the husband was allowed to take an interest thereby. Boyer v. Murphy, supra note 10.

Section 1085 was finally cited, though not as essential to the decision, in Glatts v. Henson (1947) 80 A. C. A. 248, 257, 181 P. (2d) 917, 922, but a hearing was granted by the supreme court, and the section was not mentioned in the final disposition of the case. Glatts v. Henson (1948) 31 A. C. 377,188 P. (2d) 745. 
reported judicial construction of identical statutes in other states. ${ }^{22}$ From the Code Commissioners' comment in submitting the section to the legislature it is evident that their purpose was to change the common law by allowing an interest to be taken by a stranger to the grant, eliminatmg the uncertainty then existing. ${ }^{23}$

The limitation of the provision to "natural persons," though questionable as a matter of legislative policy, will probably be taken into account $m$ any application of the section which may be made.

The section mentions only "strangers to the grant," not "strangers to the title." The Commissioners' note may be interpreted to mean that the section was intended to change only the rule of the cases cited in the note ${ }^{24}$ cases which involved "strangers to the grant" and did not distinguish "strangers to the title." Thus it is possible that the rule still is that a reservation in favor of a "stranger to the title" is ineffective, whether or not he be a "stranger to the grant." Such a limitation would be unduly restrictive, however, rendering the provision virtually nugatory, and an interpretation to that effect appears both unlikely and unnecessary. Some support for the more liberal conclusion might be found in the use made of the word "any" in the code section..$^{25}$

A more serious problem arises from the fact that the section refers, with certain qualifications, only to "a present interest." This might be interpreted to mean that a future interest in favor of a stranger, other than "the benefit of a condition or covenant respecting property," is still governed by the common law. Such a view is strengthened by the enumeration of "conditions" and "covenants" in the statute. On the other hand, the section more probably was meant to refer to an interest passing at present by force of the instrument, not a "pres-

22 Rev. Code Mont. Ann. 1935 § 6858; S. Dak. Code 1939 § 51.1313 ; N. Dak. Rev. CODE $1943 \S 47-0917$.

23 "This was not so at common law.-Hornbeck vs. Westbrook, 9 Johns., p. 73; Craig vs. Wells, 11 N.Y., p. 315 . But the law of England is now as stated in Sec. 1085.8 and 9 Vic., c. 105, Sec. 5." 1 CrvIl CODE of CALIFORNIA (1st ed. Ann. 1872) $\$ 1085$.

The California statutory provision was taken from section 482 of the Field Code. The Commissioners' Note, with shight rephrasing, was patterned after that of the New York Commissioners. Crvil CoDE of New YoRK (1865) § 482. (Proposed draft.)

The New York cases cited established the rule that a reservation, exception, or covenant would not convey any interest to or confer any benefit upon one who was not a party to the deed.

The English statute referred to read as follows: "That, under an Indenture . . . an immediate Estate or Interest . . . and the Benefit of a Condition or Covenant . . . may be taken, although the Taker thereof be not named a Party . . . "Real Property Act, 1845,8 \& 9 VIc., c. 106, $\S 5$. This was essentially reenacted in 1925: "A person may take an immediate or other interest in land or other property, or the benefit of any condition, right of entry, covenant or agreement . . . although he may not be named as a party ...." [Italics added.] The Law of Property Act, 1925, 15 GEo. V, c. 20, § 56(1).

${ }^{24}$ See note 23 supra.

25 See note 20 supra. 